\title{
Determining South Africa's Export Potential to Australia: A Panel Data Approach
}

\author{
André C Jordaan \\ Department of Economics, University of Pretoria \\ Accepted: February 2015
}

\begin{abstract}
This study explores South Africa's exports to Australia from 2000 to 2012, using both a static and a dynamic augmented gravity model. Sectors with export potential are identified, whether these are reliable and stable is considered. The largest export potential includes the apparel sectors as well as the basic metals, communication, furniture, glass, iron, leather, motor, paper and printing sectors. The most stable and reliable export sectors are the motor, machinery, iron, basic chemicals and food sectors. Although these sectors could target the promotion of South African exports, South Africa could also serve as an important source country for Australia in strengthening ties with the African continent.
\end{abstract}

Key words: bilateral trade, exports, gravity model, export potential, South Africa, Australia

JEL: F14

\section{$1 \quad$ Introduction}

South Africa and Australia have a long history of cooperation, as diplomatic relations were established as far back as 1947. A Joint Ministerial Commission was established between the two countries in 1997, which serves as the main forum for discussion and strengthening trade and economic ties. The two countries have a firm bilateral economic relationship, with their shared interest in international matters. This includes cooperation on issues such as the Commonwealth, the World Trade Organisation (WTO), the Cairns Group, the New World Wine Producers Group, climate change, protection of fisheries, human rights, human trafficking, law enforcement, defence relations and the customs regulations. South Africa and Australia are both members of the Indian Ocean Rim Association for Regional Cooperation (IOR-ARC), which facilitates trade and investment in the region (DFAT, 2013a).

Australia has a number of additional advantages in terms of international trade with South Africa. The business culture, accounting practices and the legal system are rather similar, and English is the official language in both countries. Recently, there has also been a strong business migration from South Africa to Australia.

According to Australia's trade and investment history with southern Africa, it seems that Australia was notably cautious in its exploration of foreign markets (Parliament of Australia, 1995). However, this is apparently changing, because, according to the Foreign Minister, Stephen Smith (Mercer, 2010), it makes sound economic and strategic sense to engage more with Africa. He added that increased trade could lead to greater prosperity in Africa. "Australia needs to look west to Africa. For too long, Australia had not given Africa the priority that it deserved." He concluded by stating that Australia's minerals and resources companies are conducting more projects in Africa than in any other region of the world.

Given this, it would be interesting to evaluate South Africa's exports to Australia to determine the trade prospects between the two countries. Australia ostensibly views South Africa as the gateway into the Southern African Development Community (SADC) region, as it is already the regional powerhouse. South Africa has a first-world transport, banking and telecommunications infrastructure and its gross domestic product (GDP) is seven times higher than the average GDP per capita for the sub-Saharan region (DFAT, 2013a).

Furthermore, South Africa is the $28^{\text {th }}$ largest merchandise trading partner, with the $23^{\text {rd }}$ most significant merchandise export market and the $36^{\text {th }}$ most important import market for Australia. 
South Africa is also the $17^{\text {th }}$ largest foreign investor in Australia. Investment in Australia was valued at \$A2.310 billion in 2012. Australian investment in South Africa during the same time period was valued at \$A3.024 billion, with the mining sector, agriculture, infrastructure and services being the main sectors attracting investment in South Africa (DFAT, 2013b). Bilateral trade between the two countries in 2012 was valued at $\$ A 2.233$ billion (DFAT, 2013b).

The merger of the Australian BHP and South African Billiton in 2001 created BHP Billiton, which is the largest mining company in the world. In 2012, the main Australian exports to South Africa were coal, wheat, civil engineering equipment and parts, with specialised machinery and parts valued at \$A1.788 billion. South African exports to Australia comprised passenger motor vehicles (mainly BMW Series 3), goods vehicles, specialised machinery and parts; and pig iron, valued at \$A1.281 billion (DFAT, 2013b).

Australia was South Africa's $20^{\text {th }}$ most important export destination and its $18^{\text {th }}$ most important import source worldwide during 2009 (DTI, 2010). South African exports to Australia increased by 251 per cent from 2000 to 2008. Between 2000 and 2009, the increase in exports measured 72 per cent, owing mainly to the international financial crisis. Imports from Australia to South Africa increased by 191 per cent from 2000 to 2008 and by 98 per cent between 2000 and 2009, also because of the international financial crisis. The trade balance between South Africa and Australia in 2009 showed a deficit for South Africa of approximately R3 billion (\$A 428 million) (DTI, 2010).

In 2012, South Africa's three principal export destinations were China (11.6 per cent), the United States ( 8.7 per cent) and Japan ( 6.2 per cent), while Australia (1.0 per cent) was at number 22. South Africa's three principal import sources in 2012 were China (14.4 per cent), Germany (10.1 per cent) and Saudi Arabia (7.7 per cent), while Australia (1.4 per cent) was at number 17 (DFAT, 2013b).

The top export destinations for Australia during the same period were China (31.6 per cent), Japan (18.8 per cent), South Korea (7.7 per cent), India (4.6 per cent) and the United States of America (3.6 per cent). The main sources for Australia's imports were China (18.8 per cent), the United States (11.8 per cent), Japan (7.7 per cent), Singapore (6.1 per cent) and Thailand (4.7 per cent) (DFAT, 2013b). This shows that there is the potential for enhancing trade with an African country, and South Africa could well be that partner.

Given this, the paper aims to provide some insight into South Africa's exports to Australia, seeing that the country is Australia's largest trading partner on the African continent. In addition, it would be intriguing to determine South Africa's export potential to Australia and to establish which sectors could be enhanced further to exploit this potential. The objective of this paper is thus to analyse South Africa's exports to Australia by applying a gravity-model approach. The paper also investigates the existence of any unexploited trade potential between South Africa and Australia. The rest of the paper is organised as follows. A gravity model will be discussed in Section 2, followed by the estimation methodology in Section 3. Section 4 presents the estimation results and Section 5 elaborates on the trade potential. Section 6 will conclude the paper.

\section{$2 \quad$ A gravity model}

A gravity model is an important instrument for determining the export potential and is used to analyse the relationship between the volume and direction of bilateral international trade. Tinbergen (1962) and Pöyhönen (1963) pioneered the idea of explaining bilateral trade flows using Newton's law of gravity. The economic mass of a country, generally measured by the gross domestic product (GDP), acts as the attraction factor between two countries. However, the attraction would be partially offset by the distance between the countries, which serves as a resistance factor. In theory, one would thus expect that countries with a stronger GDP, which are in close proximity to one another, would experience higher volumes of bilateral trade. Conversely, the smaller the GDP and the further away the countries are from one another, the less trade would occur. Anderson (1979) and Bergstrand $(1985,1989)$ both emphasised that the gravity model is a good representation, irrespective of the structure of the product markets. 
Being a proxy for transportation costs, distance is normally expected to be negatively related to the flow of exports i.e., the greater the distance, the higher the costs involved in trading. There is consequently a negative effect on the trade flows. However, as shown by Marimoutou, Peguin and Peguin-Feissolle (2009) and Brun, Carrère, Guillaumont and de Melo (2005), distance can play a different role in a gravity model of bilateral trade. Marimoutou et al. (2009) show in particular that the larger the GDP of the trading partner country, the less the effect of distance on trade flows.

The basic gravity model is augmented by a number of variables, such as infrastructure and differences in per capita income, to enhance the explanatory power of trade between countries (Martinnez-Zarzoso \& Nowak-Lehmann, 2003). Bergstrand $(1985,1989)$ included the population size, while Oguledo and MacPhee (1994) included a measure of the price variable. Several studies, such as those by Mátyás (1997) and Tri Do (2006), extended the gravity equation by including the exchange rate.

The basic gravity equation explains the extent of the exports between country $i$ and country $j$ in terms of three factors. These are the total supply of the exporting country $(i)$, the potential demand of the importing country $(j)$ and the various factors which represent either a resistance to or an enhancement of the trade flow between countries. This study follows a generalised gravity model specified as (Martinez-Zarzoso \& Nowak-Lehmann, 2003; Jakab, Kovacs \& Oszlay, 2001; Breusch \& Egger, 1999; Oguledo \& MacPhee, 1994):

$$
\ln X_{i j t}=C_{0}+\beta_{1} \ln E R_{j t}+\beta_{2} \ln G D P_{j t}+\beta_{3} \ln G D P S A_{i t}+\beta_{4} \ln P O P_{j t}+\beta_{5} \ln P O P S A_{i t}+\beta_{6} Z_{i j}+\varepsilon_{i j t}
$$

where $X_{i j}$ is South Africa's (country $i$ ) sectoral exports of goods to Australia (country $j$ ) during time $t, E R_{j t}$ is the nominal exchange rate ( $\mathrm{rand} / \$ \mathrm{~A}$ ) between South Africa and Australia, $G D P_{j t}$ is the domestic product of Australia and GDPSA $A_{i t}$ is the GDP of South Africa. The population of Australia is represented by $P O P_{j t}$ and $P O P S A_{i t}$ the population of South Africa, with $Z_{i j}$ representing any other factor enhancing or restricting trade between the two countries, and $\varepsilon_{i j t}$ is the normal error term.

A higher rate of exchange (depreciation of the South African rand) generally leads to an increase in exports, while a lower rate of exchange (appreciation) leads to a decrease in exports. It is therefore expected that the coefficient $\beta_{1}$ should be positive when the exchange rate depreciates and negative when the real exchange rate appreciates.

A higher level of GDP in the importing country indicates a higher level of the potential demand for imports. Similarly, a higher exporter's GDP represents increased production potential and implies increased volumes of export ability. The coefficients $\beta_{2}$ and $\beta_{3}$ are therefore expected to indicate positive signs.

According to Martinez-Zarzoso and Nowak-Lehmann (2003) and Armstrong (2007), there is no clear a priori relationship between exports and the populations of either the exporting or importing country. The estimated coefficient of the exporter's population could be positive or negative. A large local population indicates a large domestic market with high levels of consumption (absorption effect) and thus lower quantities to export (Nilsson, 2000). Large populations may also encourage the division of labour (economies of scale), which means higher production levels and thus opportunities for exporting more. In the same vein, the estimated coefficient of the trading partner's population could be positive or negative. Thus, the effects of population on both the exporting and importing country cannot be assigned a priori. It is thus expected that $\beta_{4}$ and $\beta_{5}$ will have ambiguous signs (Oguledo \& MacPhee, 1994).

This paper makes a further effort to introduce a dynamic effect. In Equation 2, it is assumed that, in any period of time, exporters exchange the products and an exact zero trade balance between two countries exists. However, because equilibrium exports are not necessarily achieved in time period t, a trade deficit or surplus normally occurs. Exporters in South Africa have to bear sunk costs, such as distribution and service networks, bringing about inertia effects in bilateral trade flows. In addition, previous investment in export-assisting infrastructure could also affect the trade relationship between countries (Sichei, Erero \& Gebreselasie, 2008). This means that, if 
South Africa exported products to certain destinations at time $t-1$, it would generally still do so at time $t$. Although still taking account of this inertia effect, certain panel studies using gravity estimations introduced dynamism (De Grauwe \& Skudelny, 2000). By relaxing the zero trade balance and incorporating the persistence effect, a partial adjustment mechanism changes exports to have the form:

$$
\left(\ln X_{i j t}-\ln X_{i j t-1}\right)=\delta\left(\ln X_{i j t}^{*}-\ln X_{i j t-1}\right)+\psi_{i j t}
$$

Incorporating this into Equation 1 and rearranging it generates;

$$
\begin{aligned}
& \ln X_{i j t}=\delta C_{0}+(1-\delta) \ln X_{i j t-1}+\delta \beta_{1} \ln E R_{j t}+\delta \beta_{2} \ln G D P_{j t}+\delta \beta_{3} \ln G D P S A_{i t}+\delta \beta_{4} \ln P O P_{j t} \\
& +\delta \beta_{5} \ln P O P S A_{t}+\delta \beta_{6} Z_{i j}+\varepsilon_{i j t}
\end{aligned}
$$

Equation 3 can now be rewritten as;

$$
\ln X_{i j t}=C_{0}^{*}+\delta^{*} \ln X_{i j t-1}+\beta_{1}^{*} \ln E R_{j t}+\beta_{2}^{*} \ln G D P_{j t}+\beta_{3}^{*} \ln G D P S A_{i t}+\beta_{4}^{*} \ln P O P_{j t}+\beta_{5}^{*} \ln P O P S A_{t}+\beta_{6}^{*} Z_{i j}+\varepsilon_{i j t}^{*}
$$

This represents a partial adjustment gravity model, where variables with asterisks in Equation 4 represent the short-term effects and $\beta_{1}$ to $\beta_{6}$ in Equation 3 represents the long-term effects. The speed of adjustment is indicated by the coefficient $\delta(0<|\delta|<1)$, which is equal to one if adjustment occurs in a one-time period.

In addition, it was decided to include the standard dynamic panel GMM, as it leads to more efficient and robust estimates, especially in the presence of possible heteroscedasticity and serial correlation. The Generalised Method of Moments (GMM) was introduced by Hansen in his famous 1982 paper (Hansen, 1982). The starting point for GMM estimation is a theoretical relation that the parameters should satisfy. The idea is to choose the parameter estimates so that the theoretical relation is satisfied as closely as possible. The theoretical relation is replaced by its sample counterpart and the estimates are chosen to minimize the weighted distance between the theoretical and actual values. GMM is a robust estimator, in that it does not need to be informed of the exact distribution of an error term (Wojcik \& Rosiak-Lada, 2007). The theoretical relation that the parameters should satisfy is usually called orthogonality conditions between some function of the parameters $f(\theta)$ and a set of instrumental variables $z t$ :

$$
E\left(f(\theta)^{\prime} Z\right)=0
$$

where $\theta$ is the parameters to be estimated. The GMM estimator selects parameter estimates so that the sample correlations between the instruments and the function $f$ are as close to zero as possible. For the GMM estimator to be identified, there have to be at least as many instruments as there are parameters to estimate.

An important contribution by Hansen's (1982) original work was to alter the requirements for instrument exogeneity. In GMM, instruments are exogenous if they satisfy a conditional mean restriction, so careful consideration of instrument exogeneity is a standard procedure in GMM empirical analysis. Instrument exogeneity, together with instrument relevance, is an important criterion when it comes to an instrument's validity. When testing instruments' relevance, an instrumental variable must satisfy the requirements of correlation with the included endogenous variable(s) and orthogonal to the error process (Baum, Schaffer \& Stillman, 2003).

\section{Estimation methodology}

A panel data approach would be used to estimate the gravity model of bilateral trade. This has many advantages, such as the role of the business cycle and the fact that the interactions between variables over a long period of time can be captured (Egger, 2000; Egger \& Pfaffermayr, 2003; Martinez-Zarzoso \& Nowak-Lehmann, 2003). Panel data involves different models that can be estimated, such as pooled, fixed and random effects. The pooled model assumes that sectors are homogeneous, while fixed and random effects introduce heterogeneity in the estimation. The pooled model is restricted and assumes a single intercept and the same parameters over time and 
across sectors. Sector-specific effects are not estimated. However, the unrestricted models (fixed or random effects models) allow the intercept and other parameters to differ across sectors. Because sectors differ from one another, there should be a decision on whether to use a random or a fixed-effect model, as the regressions include individual sectoral effects. When estimating the trade flows between a randomly-drawn sample of sectors from a large population, a randomeffects model is more appropriate. However, the fixed-effects model is preferred when estimating the flows of trade between an ex-ante pre-determined selection of sectors (Egger, 2000; MartinezZarzoso \& Nowak-Lehmann, 2003). This paper analyses sectoral trade between South Africa and Australia, so the fixed-effects model will be employed. It covers the period between 2000 and 2012.

\subsection{Univariate characteristics of variables}

Before the estimation, the univariate characteristics of the variables are analysed, using panel unit root tests. This is done to establish whether there is a potentially cointegrated relationship between the variables. If all the variables are stationary, the traditional ordinary least square (OLS) estimation can be used to estimate the relationship between the variables. If the variables contain a unit root or are non-stationary, a cointegration test should be performed. This study applies two different types of panel unit root tests. The first test is that of Levin, Lin and Chu (2002), which assumes that the autoregressive parameters are common across cross-sections. Levin, Lin and Chu (LLC) (2002) use the null hypothesis of a unit root. The second panel unit root test allows for the autoregressive parameters to vary across cross-sections as well as for individual unit root processes. The test was developed by Im, Pesaran and Shin (IPS) (2003) and combines individual sectors' unit root tests. In the IPS test, the null hypothesis assumes that all series contain a unit root, while the alternative hypothesis is that at least one series in the panel contains a unit root. IPS is a one-tailed or lower-tailed test based on $\mathrm{N}(0,1)$ distribution. The results of the panel unit root tests are presented in Table 1.

Table 1

Panel Unit Root Tests

\begin{tabular}{|l|c|c|}
\hline & \multicolumn{1}{|c|}{ LLC } & \multicolumn{1}{c|}{ IPS } \\
\hline Exports & $-7.600(0.000)^{\star \star \star}$ & $-3.726(0.000)^{\star \star \star}$ \\
\hline Exchange rate & $-8.724(0.000)^{\star \star \star}$ & $-1.410(0.103)^{\star *}$ \\
\hline Importer's GDP & $-10.124(0.000)^{\star \star \star}$ & $-3.958(0.000)^{\star \star \star}$ \\
\hline South Africa's GDP & $-8.367(0.000)^{\star \star \star}$ & $-1.999(0.021)^{\star \star}$ \\
\hline Importer's population & $-6.301(0.000)^{\star \star \star}$ & $2.879(0.998)$ \\
\hline
\end{tabular}

Notes: ${ }^{* * \star / * * / *}$ denotes rejection of the null at $1 \% / 5 \% / 10 \%$ level. Probabilities are in parenthesis.

Table 1 shows that the LLC reject the null of a unit root for all the variables. A rejection of unit roots by at least one test assumes a verdict of stationarity. That implies that a cointegration test is not required and Equations ( 3 and 4 ) can be estimated using the OLS method. The detailed data source and description are provided in the Appendix.

\section{Estimation results}

Table 2 presents the results for the fixed effects model, which estimates sector-specific effects and introduces heterogeneity. To check the poolability of the data, the F-test is performed and the results show that the null hypothesis of equality of the individual effects or homogeneity for all sectors is rejected. This confirms that a model with individual sector effects (fixed effects) is the preferred model. The Hausman test is also executed within the random effects model in order to detect misspecification or to ensure that the X-regressors and the individual effects are not correlated. The results show that the Hausman specification test $[0.000$ (1.000)] accepts the null hypothesis of no misspecification. This result therefore indicates the exogeneity of the Xregressors and there is thus no correlation between the individual effects and the X-regressors. 
The results of the static fixed effects model in Table 2 show that the coefficient of the exchange rate is positive, which indicates an increase in exports from South Africa. As the exchange rate depreciated over the sample period, it could be expected that exports would increase and the coefficient is thus consistent with theory. It therefore shows that a weaker South African exchange rate relative to the Australian dollar will enhance exports from South Africa to Australia.

An increase in Australia's GDP causes a decrease in exports from South Africa to Australia, which is in contrast with the theoretical expectations. This means that, as the Australian economy improves, fewer products are imported from South Africa and there is possibly a demand shift to more developed countries. The coefficient of South Africa's GDP is positive, indicating that exports to Australia increase as South Africa's GDP rises, in accordance with the theoretical expectations.

Table 2

Estimation results

\begin{tabular}{|c|c|c|c|c|}
\hline \multirow{2}{*}{ Variables } & \multirow{2}{*}{$\begin{array}{c}\text { Random } \\
\text { model }\end{array}$} & \multirow{2}{*}{ Static fixed effects model } & \multicolumn{2}{|c|}{ Dynamic 2SLS } \\
\hline & & & Long run & Short run \\
\hline Constant & & $21.53(11.65)^{\star \star *}$ & $22.87^{\star \star \star}$ & $10.52(5.72)^{\star \star \star}$ \\
\hline Exports (-1) & & & $0.46^{* * *}$ & $0.54(11.91)^{\star \star *}$ \\
\hline Exchange rate & & $1.39(5.33)^{\star \star \star}$ & $3.11^{* * *}$ & $1.44(4.74)^{\star \star \star}$ \\
\hline Australia's GDP & & $-1.14(-4.01)^{\star \star *}$ & $-2.95^{* \star *}$ & $-1.36(-4.32)^{\star \star \star}$ \\
\hline South Africa's GDP & & $2.04(8.16)^{\star \star \star}$ & $3.58^{* \star *}$ & $1.66(5.94)^{\star \star \star}$ \\
\hline Australia's population & & $-5.90(-5.93)^{\star \star}$ & $-8.78^{\star \star *}$ & $-4.05(-4.50)^{\star \star *}$ \\
\hline $\begin{array}{l}\text { Adjusted R-squared } \\
\text { Durban-Watson } \\
\text { Hausman test }\end{array}$ & $\begin{array}{c}0.000 \\
(1.000)\end{array}$ & $\begin{array}{l}0.955 \\
1.065\end{array}$ & & $\begin{array}{l}0.967 \\
1.950\end{array}$ \\
\hline
\end{tabular}

Notes: ${ }^{* * * * * / *}$ significant at $1 \% / 5 \% / 10 \%$ level. The $t$-statistics are in parentheses

The coefficient of the Australian population is negative, which means that a growing Australian population will cause a decline in imports from South Africa. An increase in the importer's population therefore implies that a possible division of labour (economies of scale) will be encouraged, resulting in higher local production and fewer imports from South Africa. It may also show that Australia is not particularly reliant on South African exports. South Africa's population had a positive coefficient, but was statistically insignificant and was therefore omitted from the estimation. The effect of import tariffs was also tested but was found to have the incorrect sign, although it was statistically significant. The dataset comprises 377 observations, including 13 annual observations for 29 sectors. All the variables were statistically significant and the adjusted $\mathrm{R}$-square is 0.955 . However, this model experiences persistence effects, as is evident from the relatively low Durbin-Watson statistic.

The second model estimated was the dynamic fixed effect using the 2 Stage Least Square (2SLS) approach. This model allows for heterogeneity among sectors, including the inertia effect by exporters in response to export opportunities. This model is more appropriate when it comes to the persistence effects indicated by the higher Durbin-Watson statistic. Again, the Hausman test was executed and the results show that the Hausman specification test [0.000 (1.000)] accepts the null hypothesis of no misspecification. This result therefore indicates exogeneity of the Xregressors and thus no correlation between the individual effects and the X-regressors.

Two parameter estimates were determined for the 2SLS dynamic model, producing a short- and long-run coefficient. The speed of adjustment ( $\delta$ in Equation 2 ) was 0.46 , meaning that, if an export opportunity exists in any sector, exporters from South Africa would adjust on average to meet 46 per cent of the export contract in one year and the remaining 54 per cent in the following period. On average, exporters will take advantage of export opportunities to Australia within approximately 26 months. ${ }^{1}$ The long-run coefficients are in general slightly higher than the shortrun coefficients, as there is more time available to adjust. This may indicate that there is reason to believe that increased trade between the two countries tends to be more long-run. 
The sector-specific effects estimates from the static estimation are presented in the Appendix. The sectoral or cross-section specific effects show the effect of factors that are unique to each sector but are not included in the estimation of the model. It shows that trade between South Africa and Australia differs from sector to sector, given the unique features of each sector. Table A1 shows that there are features in some sectors that promote exports from South Africa to Australia in the motor industry, machinery, iron, basic chemicals, food, metals, other chemicals, mining, electrical items, paper, base metals, communications and textiles. However, it is also shown that there are imperceptible sectoral characteristics that discourage South Africa's exports of printing, footwear, leather, glass, beverages, apparel, agriculture, rubber, minerals, transport, furniture, plastic, equipment, wood, petroleum, and other industrial products. It is important from the policy perspective to analyse these export-inhibiting factors which discourage exports from South Africa to Australia.

The results of the Generalised Method of Moments (GMM), testing the robustness of the relationships, were also favourable. The appropriate test statistic can be constructed as the J-value multiplied by the number of observations. Under the null hypothesis that the over-identifying restrictions are satisfied, the J-statistic multiplied by the number of observations is asymptotically $\chi 2$ with degrees of freedom equal to the number of over-identifying restrictions (Stock, Wright \& Motohiro Yogo, 2002). The statistic for the validity of instruments has a $\chi 2$ distribution, with 6 degrees of freedom, and takes the value of $2.714{ }^{2}$ The null of validity of instruments and overall specification of the model therefore cannot be rejected $(\chi 20.05(6)=12.59)$. The hypothesis that the full set of orthogonality conditions is valid can therefore be accepted. The results of the GMM model are shown in Table 3.

Table 3

Panel GMM

\begin{tabular}{|c|c|}
\hline Variables & Coefficient (t-statistics) \\
\hline Constant & $-2959.99(-1.70)^{*}$ \\
\hline GDP Australia & $-366.91(-1.688)^{*}$ \\
\hline GDP South Africa & $-268.06(1.51)^{\star}$ \\
\hline Population Australia & $1999.06(1.62)^{\star}$ \\
\hline Exchange rate & $-334.09(-1.33)^{*}$ \\
\hline $\begin{array}{l}\text { Instrumental rank } \\
\text { J-statistic }\end{array}$ & $\begin{array}{l}6 \\
0.00783\end{array}$ \\
\hline
\end{tabular}

\section{Trade potential}

To determine the within potential exports from South Africa to Australia, the estimated fixed effects of Equation (4) are simulated. The estimated export potential is then compared with actual exports to find out whether there is any unexploited trade potential in the respective sectors. The results show that the sectors indicating the greatest export potential are presented in Figure 1. They include the apparel, basic metals, communication, furniture, glass, iron, leather, motor, paper and printing sectors. Other sectors indicating a relatively small potential include footwear, metal products, minerals, products from other industries and transport, where potential exports still exceed actual exports. From the South African perspective, it is important to promote exports from these sectors to gain the benefits from this unexploited trade potential. However, a further analysis of all these sectors is important in order to determine and identify possible factors that may inhibit the promotion of actual exports, given the unexploited potential. 
Figure 1

Export Potential Per Sector

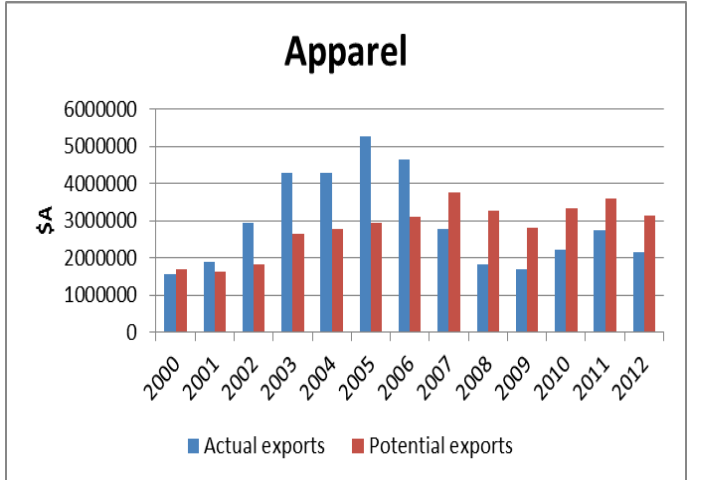

\section{Communication}

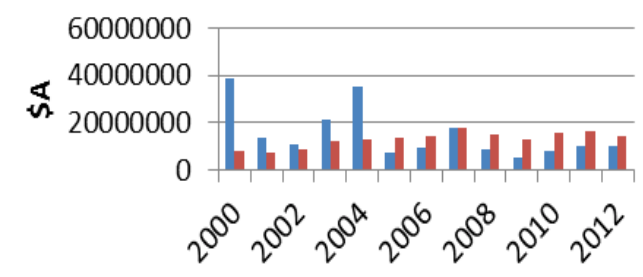

Actual exports Potential exports
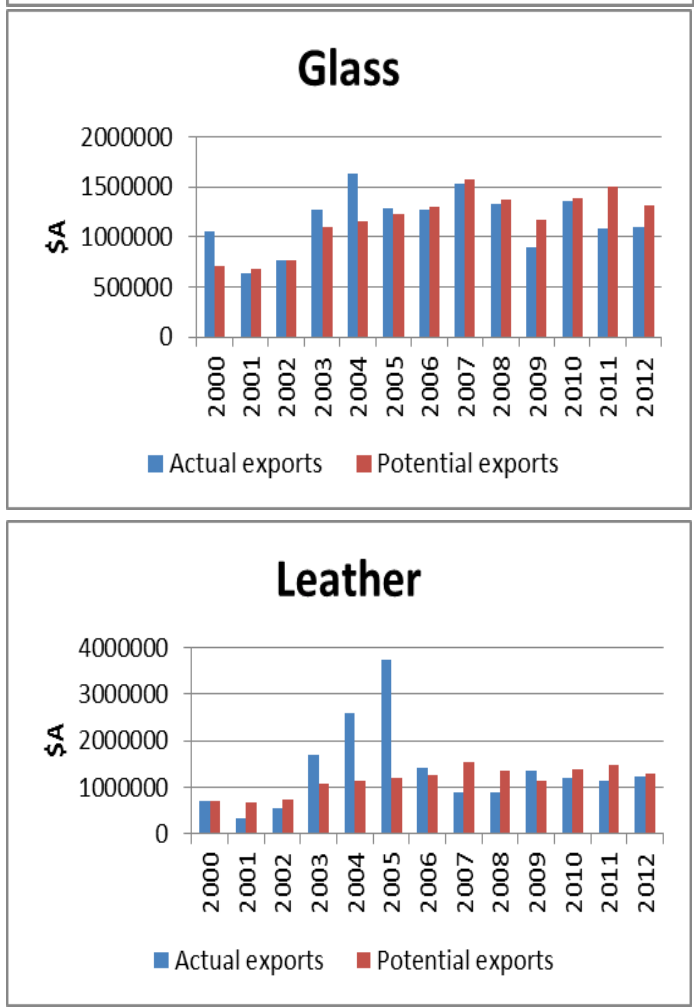
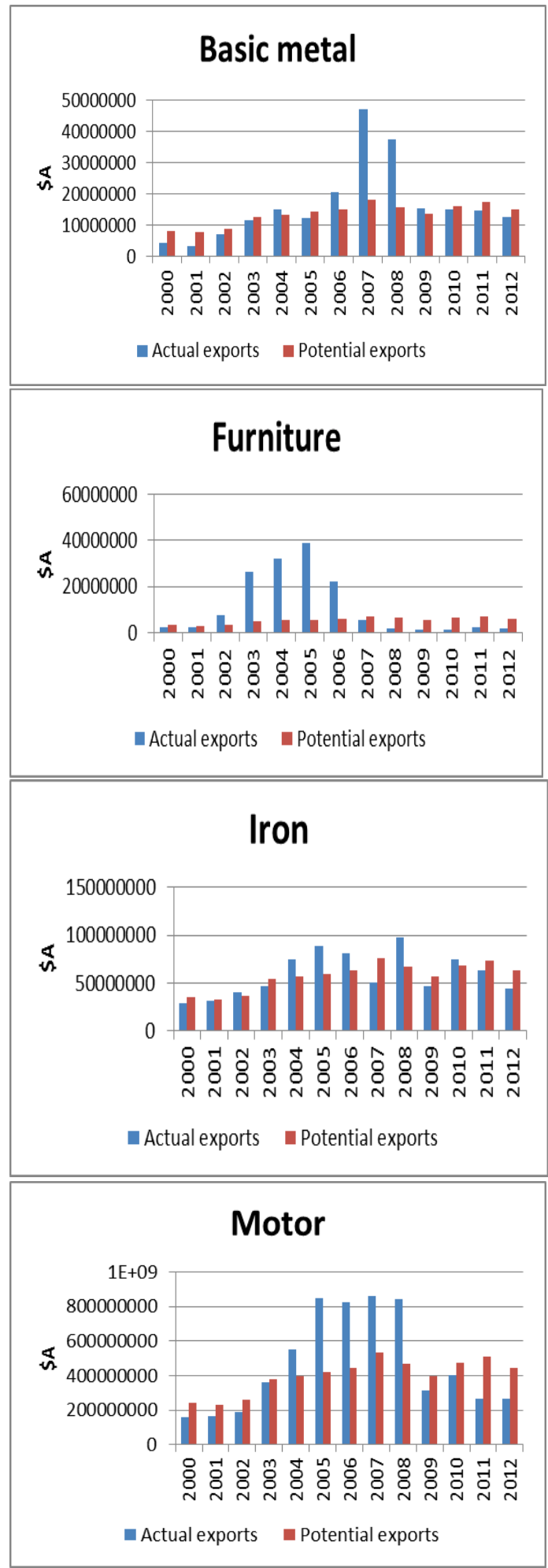

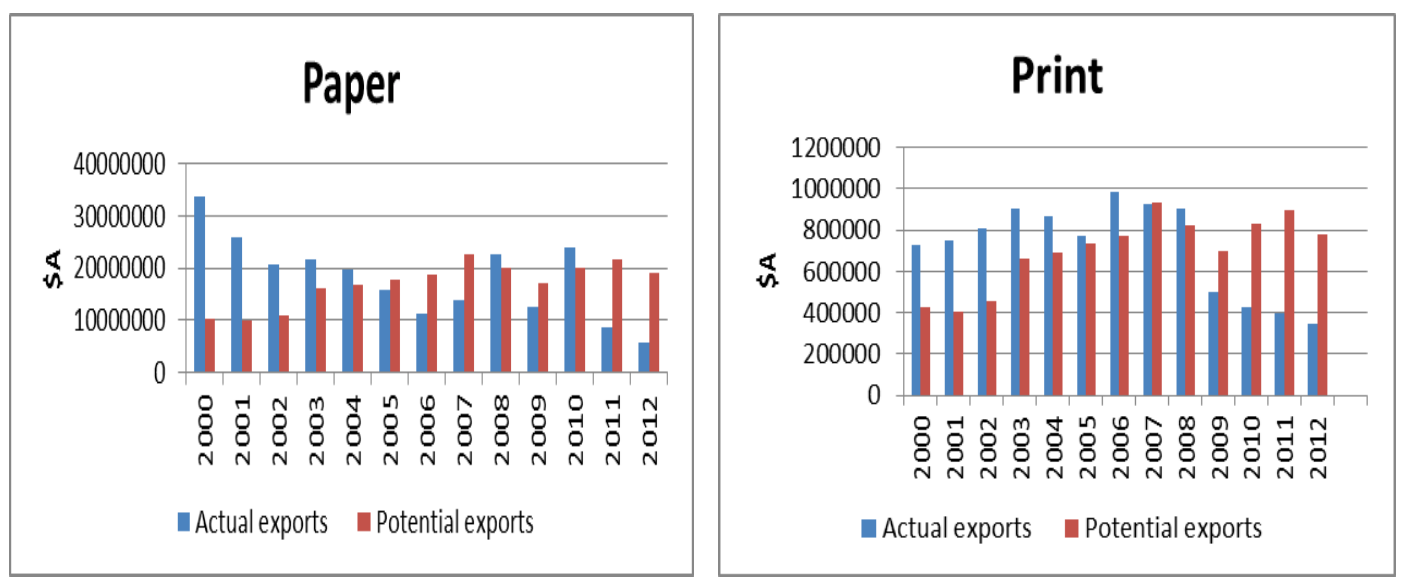

Another point of interest is that the actual exports exceed the potential exports in some sectors, including the agriculture, basic chemicals, beverages, electric, equipment, food, machinery, mining, other chemicals, petroleum, plastic, rubber and the textile and wood sectors. A further analysis of these sectors would provide important information on the reasons why the actual exports exceed the potential exports.

\subsection{Variability of potential trade}

Although the sectors with unexploited trade potential have now been identified, it is also important to determine which of them are actually stable, and reliable export sectors. Stability of export flows in a specific sector are of the utmost importance, as job security and revenue generation depend on them. From the estimation, the paper also determines this stability by using the coefficient of variation (CV) computed from the stochastically-solved model. This can be computed in a percentage as follows:

$\% \mathrm{CV}=($ Standard deviation/Mean $) \times 100$

The coefficient of variation provides an indication of the South African export sectors in Australia and whether they can be classified as stable or not. The lower the CV, the more stable and thus the more reliable the export sector; and the higher the $\mathrm{CV}$, the less stable and reliable the sector. With reference to the group of sectors included in the study, Figure 2 shows South Africa's 12 most stable and reliable sectors exporting to Australia. The most stable and reliable sector is the motor industry (1.42) and the $12^{\text {th }}$ most stable is the communication sector (1.71). However, the motor industry currently receives the highest level of government incentives, previously under the Motor Industry Development Plan (MIDP), which was adjusted in 2012 and then replaced by the Automotive Production and Development Programme (APDP) in 2013. From the perspective of policy, export promotion policies should be directed to the more stable export sectors not receiving any government assistance. Policies directed at improving the exports from the less stable sectors with a high CV should also be pursued.

Sectors which have unexploited trade potential and are among the most stable and reliable export sectors to Australia include the motor, iron, paper, basic metal, communication and metal product sectors. Policy-makers should pursue the correct policy mix with these sectors, as both unexploited trade potential is available and seems to score reasonably well in terms of reliability and stability. This could ensure a consistent flow of foreign currency revenue to South Africa and increase job creation possibilities. 
Figure 2

Coefficient of variation

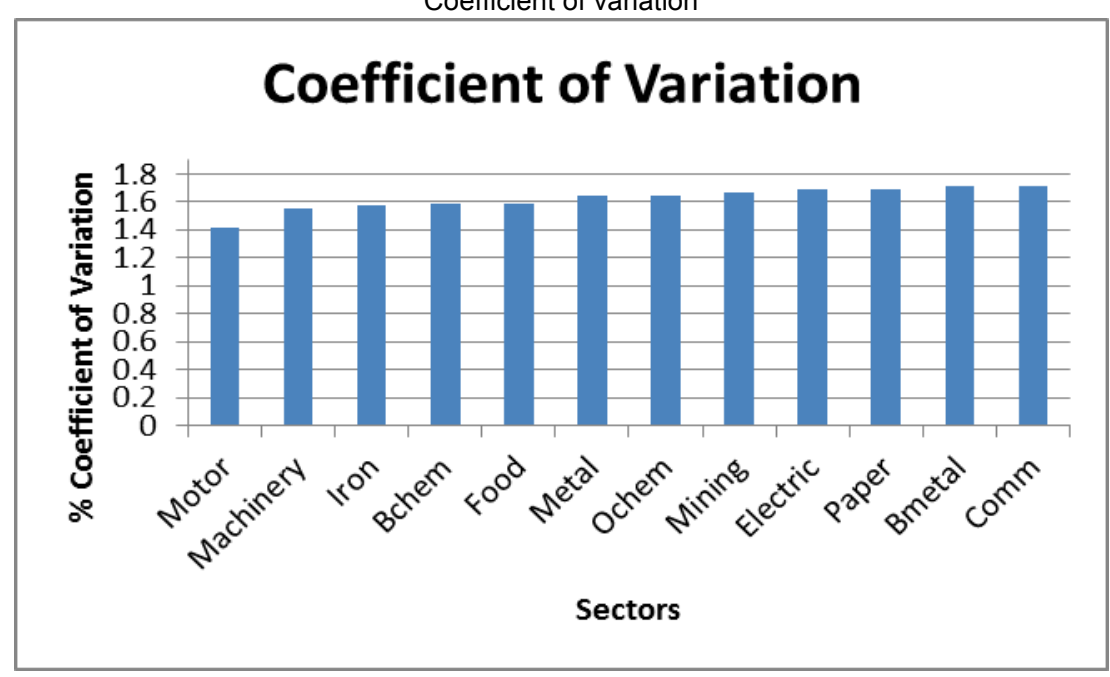

\section{Conclusion}

This study identifies the South African exports to Australia that had unexploited potential for the period 2000 to 2012 using a gravity model approach. The coefficient of South Africa's exchange rate was positive and was thus aligned with theory. Exports from South Africa decreased as Australia's GDP increased and were in contrast with theory. The coefficient of South Africa's GDP was positive and in line with theoretical expectations. Australia's population had a negative coefficient, indicating a decreased demand for South African products as the Australian population increased Large populations could encourage the division of labour (economies of scale), which would mean higher production levels and a smaller import demand for South African products.

Export opportunities for South African exporters were utilised, as 46 per cent of the export contract was met within the first year, while the remaining 54 per cent was met during the following period. It seemed that, on average, South African exporters would take advantage of export opportunities within 26 months. As the coefficients were generally larger over the long run, it appears that the trade relationship between the two countries could be enhanced over the longer term. The paper identifies unexploited trade potential in the apparel, basic metals, communication, furniture, glass, iron, leather, motor, paper and printing sectors. Of these, the most reliable and stable export sectors included the motor, iron, paper, basic metals and communication sectors.

The results of this study could provide important information to guide policy-makers in developing tailor-made policies to ensure that the export potential is exploited in order to accelerate growth and job creation in South Africa. The success rate could be further enhanced by focussing on reliable and stable export sectors as indicated by the coefficient of variation. The allocation of resources and support could be directed to the sectors with the highest level of unexploited potential. The paper provides important avenues to be considered for enhancing exports to Australia. Australia may also re-evaluate its trade links with South Africa in particular and Africa in general. In addition, Australia could use South Africa as an important source country in the African context to give the continent the "priority it deserves". Australia could therefore contribute to Africa's increased productivity levels, enhanced export flows and improved growth. Promoting bilateral trade between South Africa and Australia could establish these countries as the future pillars of strength between the two continents. 


\section{Endnotes}

$1 \quad 1 / 0.46 \times 12$ months $=26.08$ months

2 J-static of $0.0078 \times 348$ observations as the reported J-statistic in E-views

\section{References}

ARMSTRONG, S. 2007. Measuring trade and trade potential: A survey. Asia Pacific Economic Papers, No. 368.

ANDERSON, J.E. 1979. A theoretical foundation for the gravity equation. American Economic Review, 69(1):106-116.

BAUM, C.F., SCHAFFER, M.E. \& STILLMAN, S. 2003. Instrumental variables and GMM: Estimation and testing. The Stata Journal, 3(1):1-31.

BERGSTRAND, J.H. 1985. The gravity equation in international trade: Some microeconomic foundations and empirical evidence. Review of Economics and Statistics, 67(3):474-80.

BERGSTRAND, J.H. 1989. The generalised gravity equation, monopolistic competition and the factorproportions theory in international trade. Review of Economics and Statistics, 71(1): 143-53.

BREUSCH, F. \& EGGER, P. 1999. How reliable are estimations of East-West trade potentials based on cross-section gravity analyses? Empirica, 26(2):81-99.

BRUN, J., CARRÈRE, C., GUILLAUMONT, P. \& DE MELO, J. 2005. Has distance died? Evidence from a panel gravity model. The World Bank Economic Review, 19(1):99-120.

DE GRAUWE, P. \& SKUDELNY, F. 2000. The impact of EMU on trade flows. Weltwirtshaftliches Archiv, 136:381-402.

DEPARTMENT OF FOREIGN AFFAIRS AND TRADE (DFAT). 2013a. South Africa. Available at: http://www.dfat.gov.au/ [accessed: 2013-12-10].

DEPARTMENT OF FOREIGN AFFAIRS AND TRADE (DFAT). 2013b. South Africa country brief. Available at: http://www.dfat.gov.au/geo/south africa [accessed 2013-12-10].

DEPARTMENT OF TRADE AND INDUSTRY, (DTI). 2010. South African Trade - Australia. Available at: http://www.thedti.gov.za/econdb/raportt/R100501.html [accessed: 2013-12-10].

EGGER, P. 2000. A note on the proper econometric specification of the gravity equation. Economic Letters, 66:25-31

EGGER, P. \& PFAFFERMAYR, M. 2003. The proper panel econometric specification of the gravity equation: A three-way model with bilateral interaction effects. Empirical Economics, 28:571-80.

HANSEN, L. 1982. Large sample properties of generalized method of moments estimators. Econometrica, 50(3):1029-1054.

IM, K.S., PESARAN, M.H. \& SHIN, Y. 2003. Testing for unit roots in heterogeneous panels. Journal of Econometrics, 115:53-74.

JAKAB, Z.M., KOVACS, M.A. \& OSZLAY, A. 2001. How far has regional integration advanced? An analysis of the actual and potential trade of three central European countries. Journal of Comparative Economics, 29:276-92.

LEVIN, A., LIN, C.F. \& CHU, C. 2002. Unit roots tests in panel data: asymptotic and finite sample properties. Journal of Econometrics, 108:1-24.

MARTINEZ-ZARZOSO, I. \& NOWAK-LEHMANN, F. 2003. Augmented gravity model: an empirical application to Mercosur-European Union trade flows. Journal of Applied Economics, 6(2):291-316.

MARIMOUTOU, V., PEGUIN, D. \& PEGUIN-FESSOILLE, A. 2009. The 'distance-varying' gravity model in international economics: is the distance an obstacle to trade? Economics Bulletin. 2(2):1157-73.

MÁTYÁS, L. 1997. Proper econometric specification of the Gravity model. World Economy, 20(3):363-68.

MERCER, P. 2010. Australia pursues trade, better relations with Africa. Available at: http://www1.voanews. com/english/news/africa/pan/Australia-Pursues-Trade-Better-Relations-with-Africa [accessed: 2013-12-10].

NILSSON, L. 2000. Trade integration and the EU economic membership criteria, European Journal of Political Economy, 16:807-27.

OGULEDO, V.I. \& MACPHEE, C.R. 1994. Gravity models: a reformulation and an application to discriminatory trade arrangements, Applied Economics, 26:107-120. 
PARLIAMENT OF AUSTRALIA. 1995. Australia's trade and investment with southern Africa. Chapter 6. Available at: http://www.aph.gov.au/house/committee/jfadt/africa/Afrch 6.pdf [accessed 2010-05-26]. PÖYHÖNEN, P. 1963. A tentative model for the volume of trade between countries, Weltwirtschaftliches Archiv, 90:93-99.

SICHEI, M., ERERO, J.L. \& GEBRESELASIE, T. 2008. An augmented gravity model of South Africa's exports of motor vehicles, parts and accessories. South African Journal of Economic and Management Services, 11(4):494-510.

STOCK, J.H., WRIGHT, J. \& YOGO, M. 2002. GMM, weak instruments and weak identification. Paper delivered at the Journal of Business and Economic Statistics symposium on GMM. Washington.

TINBERGEN, J. 1962. Shaping the world economy: Suggestion for an international economic policy. New York: The Twentieth Century Fund.

TRI DO, T. 2006. A gravity model for trade between Vietnam and twenty-three European countries, Unpublished Doctorate Thesis, Department of Economics and Society.

WOJCIK, P. \& ROSIAK-LADA, K. 2007. Estimating generalized method of moments models. Bank of England.

\section{Appendix}

Sectors used in the estimation and their specific or fixed effects

\section{Positive fixed effects:}

Motor industry

3.766

Mining

0.827

Machinery

Electric

0.643

Iron

Paper

0.606

Basic chemicals

1.701

Base metals

0.374

Food

1.660

Communications

0.349

Metals

1.128

Textiles

0.117

Other chemicals

1.089

Negative fixed effects:

$\begin{array}{ll}\text { Printing } & -2.583 \\ \text { Footwear } & -2.295 \\ \text { Leather } & -2.082 \\ \text { Glass } & -2.067 \\ \text { Beverages } & -1.236 \\ \text { Apparel } & -1.197 \\ \text { Agriculture } & -0.836 \\ \text { Rubber } & -0.719\end{array}$

$\begin{array}{ll}\text { Minerals } & -0.636 \\ \text { Transport } & -0.535 \\ \text { Furniture } & -0.528 \\ \text { Plastic } & -0.470 \\ \text { Equipment } & -0.369 \\ \text { Wood } & -0.347 \\ \text { Petroleum } & -0.199 \\ \text { Other industries } & -0.126\end{array}$

Data description and sources

The study covers the period 2000 to 2012, using annual data. Twenty nine South African export sectors to Australia were included in the estimation. The data for exports, gdp, populations and exchange rates were obtained from the Quantec website: www.quantec.co.za. 